\title{
小型船舶等の電子的視認性の向上に関する基礎研究
}

\author{
平畠英隆*、林尚吾**
}

\section{A Basic Study on Enhancement of Electrical Visualization for Small Boat}

\section{Hidetaka HEIBATAKE and Shogo HAYASHI}

\begin{abstract}
To decrease collision disaster, authors examined early detecting of small boats with the enhancement of an Electrical Visualization.

Most small boats are made by FRP, but there is few observation on its radar cross section. The authors measured Radar Cross Section (RCS) of small boats. As results, RCS of boats of less than $5 \mathrm{G} / \mathrm{T}$ was $6 \mathrm{~m}^{2}$ and RCS of bigger boats was $15 \mathrm{~m}^{2}$. The RCS is not so small, however in actually, it is difficult to detect these small boats by radar. The authors thought that it was difficult to detect small boats even if small radar reflector was installed for them, because big radar reflector is not suitable for them.

So the authors make a proposal of a radar transponder operating at out-band of radar frequency band with small output power using solar power cell, communication system and network.
\end{abstract}

Keywords : Sea Disasters, Small Boat, Visualization, Radar Cross Section, FRP

キーワード：要救助海難、小型船船、視認性、レーダ断面積、FRP

\section{1. はじめに}

平成 15 年から 19 年において発生した船舶同士の 衝突海難隻数は年平均で 780 隻であり、漁船が関係 するものが約 40 \%を占めている(1)。衝突海難の原 因の一つが相手船の発見の遅机にある。見張りの基 本は目視とレーダによる継続的な監視にあるが、小
型船舶等はその船体の小ささや海面上の低さ等から 早期の発見が難しく、また確実な通信手段がないた め衝突回避や救助を迅速に行うことができないとい う問題がある。

小型船舶等の船体の多くはFRP (Fiber Reinforced Plastic) 製である。レーダに映りにくい素材である

* 学生会員 東京海洋大学大学院海洋科学技術研究科（干135-8533 東京都江東区越中島 2-1-6)

** 正会員 東京海洋大学海洋工学部 hayashis@kaiyodai. ac. jp 
ため、レーダ断面積を拡大してレーダに映りやすく する方策として、小型船舶にはレーダレフレクタを 装着することが義務化されている。しかし漁船に関 して実際に装着率を調査すると、東京湾内の調査例 では $3.7 \%$ 、房総半島の太平洋岸の某漁港での調査 例においても $8.1 \%$ に留まっているのが現状であっ た。

レーダ映像上で小型船舶等が確認しにくいことは 一般に知られているが、そのレーダ断面積に関する 資料、特に FRP 製小型船舶（以下 FRP 船）に関する ものは極めて少なく富山商船高等専門学校の故稲垣 正機助教授が指導した卒業研究（昭和 55、56 年度） での事例しか見ていない。複雑な形状の物体のレー ダ断面積については、理論值を求めることは難しく、 実物またはスケールモデルを用いて実測している ${ }^{(2)}$ 。 そこで本論文では、FRP 船（主として漁船）のレー ダ反射信号を収集・解析して、そのレーダ断面積 (Radar Cross Section) を求めることから始めた。 そして、レーダその他の電子機器で物標を認識す ることを「電子的視認性」と定義し、FRP 船のレー ダ断面積の実態を踏まえた上で、レーダ以外の電子 的視認性の向上について小電力通信機器や携帯電話 を使用する通信システムやネットワークシステムに よる方策についてまとめた。

\section{FRP 船のレーダ断面積}

\section{1 レーダ方程式とハイトパターン}

レーダの電波は、直接波と海面反射波の距離差㧍 よび反射時の位相差によって干渉を起こす。干渉を 考慮したレーダ方程式は次式で表わされる。

$$
P_{R}=\frac{P_{t} G^{2} \lambda^{2} \sigma}{(4 \pi)^{3} R^{4}} \cdot 16 \sin ^{4}\left(\frac{2 \pi a_{1} a_{2}}{R \lambda}\right) \cdots
$$

ただし、

$P_{t}$ : 送信電力、 $P_{R}$ : 受信電力、 $\lambda$ : 波長、

$G$ : アンテナ利得、 $\sigma:$ レーダ断面積、

$a_{1}$ ：地球等価半径を考慮したアンテナ高、

$a_{2}$ : 地球等価半径を考慮した物標の海面からの高さ、

$R:$ 物標までの距離
(1) 式より、受信電力は、レーダの送信電力等の諸 元値の他に、物標のレーダ断面積、物標の海面から の高さ、および距離によって変化することがわかる。 (1) 式の受信電力と距離の関係を表す曲線をハイト パターンという。観測によって得た FRP 船の受信電 力からレーダ断面積を求めるとき、異なった距離か らの受信電力の計測データとハイトパターンが最も 一致するように考慮して求める。

なお物標の高さとは、船舶を対象として受信電力 を実測する場合は、海面から煙突またはブリッジの 高さの $2 / 3$ 程度を有効反射高さとみなせることが害 験によって求められている(3)。

\section{2 計測方法}

FRP 船の多い港付近で、港内外を 3 海里程度にわ たって見渡せる場所を選び、舶用レーダを搭載した 東京海洋大学のレーダ車を設置して、FRP 船のレー ダ反射波を計測した。図 1 に示すように、対象とす る船舶を含む範囲を任意に選択し、方位方向に約 0.3 度、距離方向に約 $30 \mathrm{~cm}$ の間隔で受信電力をデジ タル化して保存した。レーダ車搭載のレーダは、周 波数 $9.4 \mathrm{GHz}$ 、送信出力 $25 \mathrm{k} \mathrm{w}$ 、ビーム幅 $1^{\circ}$ の舶用 レーダである。

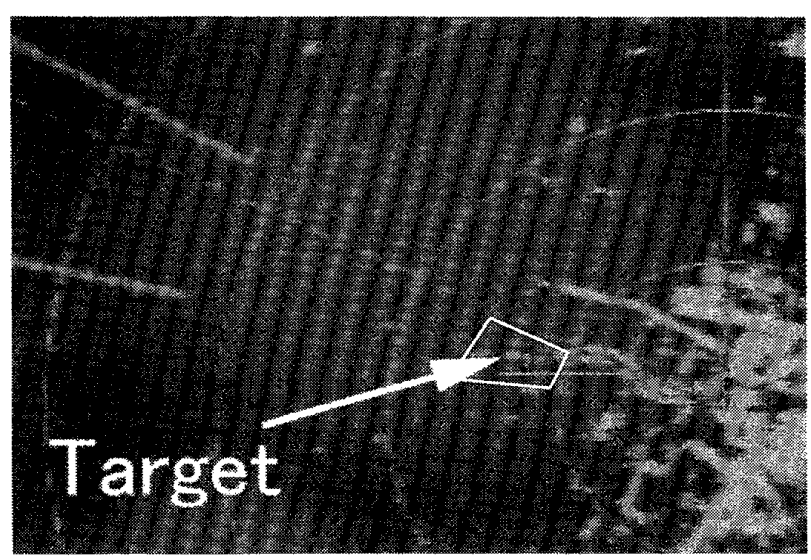

Fig.1 Sample of Data Acquisition Area

観測場所は種々の制約があり、主として次の 2 ヶ 所で行なった。アンテナ高は海面からの害測である。 (1)観測日時: 4 月 7 日

観測場所 : 千葉県富津市富津漁港岸壁

アンテナ高 : $3.8 \mathrm{~m}$ 
(2)観測日時：5月 12 日

観測場所 : 千葉県勝浦市浜勝浦駐車場

アンテナ高 : $42.7 \mathrm{~m}$

\section{3 計測結果と考察}

航行しているFRP 船からの受信電力を記録し、距 離が異なる複数のデータを収集した。計測した FRP 船はのべ 16 隻、すべて漁船である。大きさは数トン から十数トン程度であったが、漁船の場合、5トン を境に等級分けされており、登録番号によって識別 が容易であるので、計測データもそれに応じて分類 した。有効反射高さは 5 トン未満は $0.8 \mathrm{~m} 、 5$ トン以 上は $2 \mathrm{~m}$ である。なお本論文では総トン数 5 トンを 5 トンと表記する。

図 1 に示したデータ収集範囲から該当船舶の範囲 を選択し、ノイズを除去して最も強い值をその時の 受信電力とした。

図 2(a)はアンテナ高 $3.8 \mathrm{~m}$ のときの 5 トン未満の FRP 船の受信電力 (黒点) とハイトパターンである。

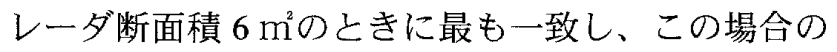
レーダ断面積を $6 \mathrm{~m}^{2}$ とし。図 2(b)はアンテナ高 3.8 $\mathrm{m}$ で 5 トン以上の FRP 船について同様に求めたもの

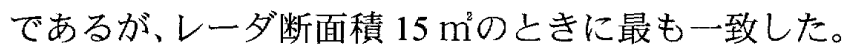
また网 2(c)は 5 トン未満の FRP 船についてアンテナ 高 $42.7 \mathrm{~m}$ ときのデータであるが、レーダ断面積は $6 \mathrm{~m}^{2}$ となった。

ここで、ハイトパターンからレーダ断面積 $6 \mathrm{~m}^{2}$ の 船舶の有効探知距離を求める。舶用レーダにおいて、 発見・探知の目安とされる受信電力は一般にー $80 \mathrm{dBm}$ としており、図2 (a)より、その距離は約 1.6 海里と 求められる。

\section{3. 小型船舶等の電子的視認性の向上につい}

$\tau$

国際標準化機構では、標準的な $9.4 \mathrm{GHz}$ 帯のレーダ で 5 海里離れた小型船舶を探知するための対策とし て、レーダ断面積が $7.5 \mathrm{~m}^{2}$ のレーダレフレクタを海 面からの高さ $4 \mathrm{~m}$ に設置することを規格化しようと している。この条件に基づいたハイトパターンを図

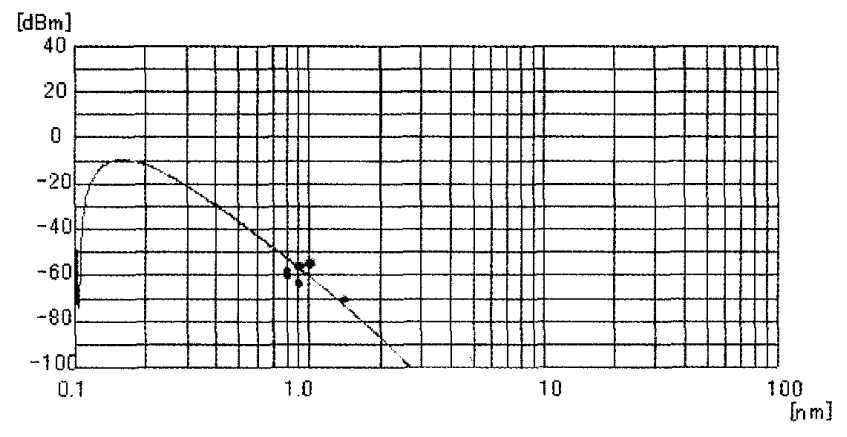

Antenna Height:3.8[m]

Radar Cross Section:6[m²]

Fig.2 (a) Signal Level of Radar Reflection of Small Boats (under $5 \mathrm{G} / \mathrm{T}$ )

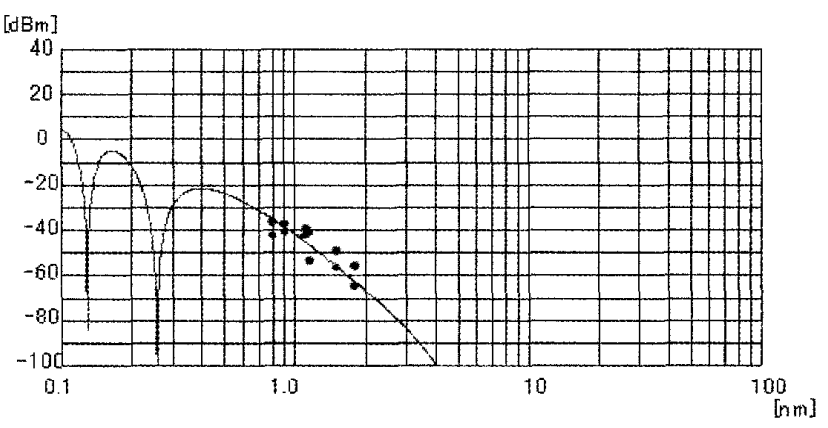

Antenna Height:3.8[m]

Radar Cross Section: $15\left[\mathrm{~m}^{2}\right]$

Fig.2 (b) Signal Level of Radar Reflection of Small Boats (over $5 \mathrm{G} / \mathrm{T}$ )

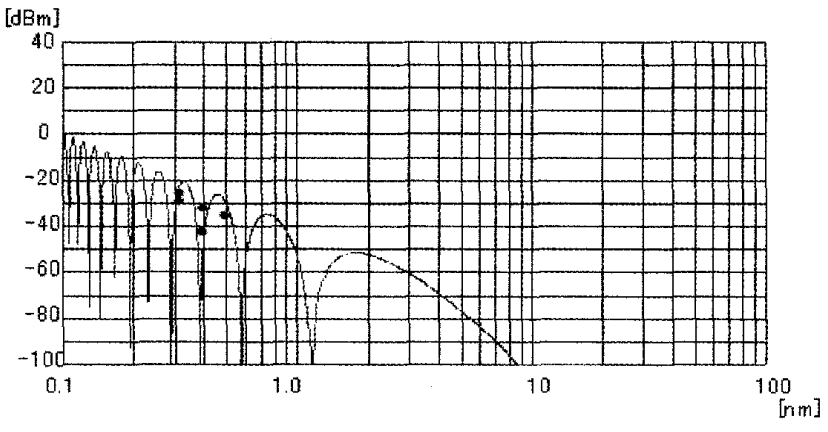

Antenna Height: $42.7[\mathrm{~m}]$

Radar Cross Section:6[ $\left.\mathrm{m}^{2}\right]$

Fig.2 (c) Signal Level of Radar Reflection of Small Boats (under $5 \mathrm{G} / \mathrm{T}$ ) 
3 に示す。有效探知距離は約 3.5 海里である。2.3 節で求めたように、レーダ断面積 $6 \mathrm{~m}^{2}$ では 1.6 海里 であったので約 2 倍に延びたことになるが、基準の 5 海里には届かない。さらに、7.5 m²レ一ダレフレ ク夕を 5 トン未満の船舶に装備するには大きさと重 さの点で厳しい内容である。

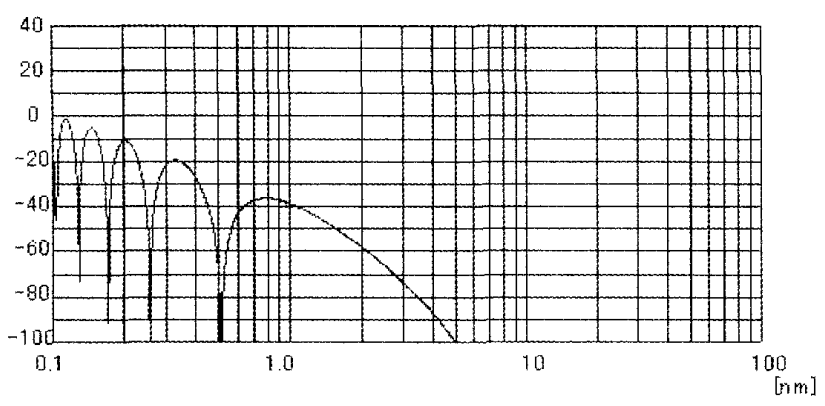

Antenna Height:3.8[m] Target Height:4[m] Radar Cross Section: $7.5\left[\mathrm{~m}^{2}\right]$

Fig.3 Signal Level of Radar Reflector of International Organization for Standardization

したがって、レーダレフレタタによる視認性向上 したがって、レーダレフレクタによる視認性向上以 外の方法が必要であると考え、現状および可能性に ついて検討した。

\section{1 電子的視認性の定義}

視認性とは、本来肉眼で使用される用語であるが、 電子工学的手法を基礎に対象の存在を認知する性能 を「電子的視認性」と定義する。わかりやすい例と して、レーダ映像上で対象物標を視覚的に表示する 手法が挙げられる。他に、通信により存在位置を表 亦するような AIS(Automatic Identification System)で の位置表示や ECDIS(Electronic Chart Display and Information System)、レーダとの連動による位置表示 も電子的視認性として含めることとする。さらには 将来、各船舶が中継局なって局所的に無線によるネ ットワークを構成し、それぞれの位置を相互に通信 しあい、画面上にその存在を認識することも視認と 考えている。小型船舶の電子的視認性の向上の方策
として最近検討されている内容を表 1 にまとめる。

\section{2 レーダに対する電子的視認性の向上}

\section{2.1 現状と問題点}

レーダに対する電子的視認性を向上させるために、 レーダレフレクタの設置について国際規格化がすす んでいることはすでに述べた。小型船舶には設置困 難な大きさであり、レーダ断面積も不十分である可 能性があるが、さらにもうひとつ、世界的な問題が 生じている。

レーダレフレクタの水平面のレーダ断面積の性能を 規定するために、SPL (Stated Performance Level) という手法が検討されている。この SPL では、無指 向性の能力が重視され、反射パターンの強弱の差が 大きいコーナ・レフレクタには厳しい規格となって いる。つまり全体の平均が国際的に決められた数值 に合致するためには、7.5 m²よりさらに大きなレー ダレフレクタが必要という結果となる。水平面反射 パターンの強弱の差が少ない反射特性を満たすには、 ルーネベルグレンズ型の無指向性の特性が要求され る。しかし、現在のルーネベルグレンズ型の製品は 重量があり、価格の点でも解決すべきことが多い。

これらを解決する方法として、英国主導の Radar Target Enhancer（RTE：レーダ映像強調装置）が 提案されている。これは、簡単な送信用と受信用の アンテナを単純な増幅装置に接続したものである。 使用しているアンテナが単純なスロットアンテナで あることから、水平面指向性が無指向性に近い。し かし、送信用と受信用のアンテナの結合によって、 自己発振を生じ、レーダ映像に妨害を起こすことが 日本国内の屋内および海上実験において観測されて おり、危険な装置であることが指摘されている ${ }^{(4)}$ 。

\section{2.2 新しい方式の提案と展望}

筆者らは前項の問題点を解決する新しい方式とし て、小型帯域外レーダビーコンを提案している ${ }^{(4)}$ 。 トランスポンダとして動作するRadar Beaconには、

- 帯域内 Beacon (In-Band Beacon)

- 帯域外 Beacon (0ut-Band Beacon) 
Table 1 Enhancement of Electrical Visualization for Small Boat

\begin{tabular}{|c|c|c|}
\hline & \multirow{4}{*}{$\begin{array}{l}\text { Enhancement of } \\
\text { Detectability using } \\
\text { Radar }\end{array}$} & Enhance Radar Cross Section \\
\hline & & Install/Enlarge Radar Reflector \\
\hline & & Install Radar Transponder \\
\hline & & Install SART for Small Boat \\
\hline \multirow{9}{*}{$\begin{array}{l}\text { Enhancement } \\
\text { of Electrical } \\
\text { Visualization } \\
\text { for small boat }\end{array}$} & \multirow{4}{*}{$\begin{array}{l}\text { Enhancement of } \\
\text { Recognition using } \\
\text { Communication }\end{array}$} & Fxamine Low Power Communication \\
\hline & & Cellular Phone System \\
\hline & & Examine RFID \\
\hline & & Examine Simplified-type AIS \\
\hline & & Install EPIRB \\
\hline & & Install PLB \\
\hline & \multirow[t]{3}{*}{$\begin{array}{ll}\text { Organizing } & \text { of } \\
\text { Network System } & \end{array}$} & $\begin{array}{l}\text { Data is communicated while relaying } \\
\text { between each ship in the area including the } \\
\text { base station }\end{array}$ \\
\hline & & 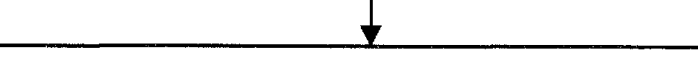 \\
\hline & & Several Proposals \\
\hline
\end{tabular}

の 2 つの形式がある。

帯域内 Beacon は、レーダが送受信する周波数帯の 中で応答信号を発するため、応答信号があるときは 常にレーダ映像上に表示され、表示・非表示を選択 できない欠点があるが、レーダの改造は不要という 利点がある。この方式で一般的に利用されてきたの が Raconである。

帯域外 Beacon は、応答信号をレーダが送受信する 周波数帯の数十MHz の帯域外で応答するものであ る。通常のレーダ映像には表扎ないが、同調調整に より Beaconの信号が表示される。つまり表示したい ときだけ表示できる利点がある。また Beaconからの 信号は、レーダ自身が送信した周波数帯からはずれ ているためクラッタに埋もれることがなく、送信出 力 $10 \mathrm{~mW}$ という小電力でも 1.3 海里までは到達するこ とが分かっている ${ }^{(5)}$ 。送信出力 $10 \mathrm{~mW}$ であ机ば、周 辺制御回路を考慮しても数W の消費電力で可能であ り、太陽電池パネルと 2 次電池で運用可能である。
防水構造を持たせることで発電機を持たない甲板の ない小型のボートでも装備が可能である。さらに RTE のような自己発振の危険性は完全に排除できる。 応答信号を符号化すれば自動処理も可能となり、表 示・非表示や表示記号の選択も自動化できる可能性 がある。ただし自動化するためにはレーダ側にはア ダプタ設置などの改造が必要である。

レーダによる電子的視認性の向上のためには、今 後この方式の研究を進める予定である。

\section{3 通信による電子的視認性の向上}

\section{3.1 現状と問題点}

海上における通信としては、AIS が利用可能とな る以前は国際 VHF による呼び出しが主流であった。 非効率的な手法であるが、大型船同士の共通の通信 手段である。これとは周波数が異なるが、漁船同士 にも共通の通信手段がある。しかしプレジャーボー トも含めた全体に共通の通信手段はまだ確保されて 
おらず、全体を含めたシステムの構築が現在検討さ れている課題である。

音声以外の通信としては、大型船等では現在AIS が利用されている。AIS（Class-A）はGPSで計測し た位置データや関連する各種の情報を時々刻々送信 しているので、相手船の位置や針路速度をレーダな どの画面上に表示できる。筆者らは世界的な動向で あるAIS（Class-B）や日本向けに日本語を表示でき る簡易型 AIS も検討してきた。簡易型 AIS について は漁船用のチャンネルを検討し、海上実験まで行っ た成果が報告されている(6)。

\section{3.2 共通する方式の提案と展望}

音声によらない通信による電子的視認性の向上の 一方法として、データ通信ネットワークが簡易 AIS の開発研究において検討された ${ }^{(6)}$ 。大型船から漁船、 プレジャーボートまで対象とするので、外国船との 操船意思の交換などには言語上の制約の少ない絵文 字や記号を含むデー夕通信が即時に行われることが 有効であると考えている。筆者らは、海上にお梳る 共通システムの端末装置として、社会基盤が十分に 整備され、また広く普及している点を重視して携帯 電話を考慮している。しかし大型船まで対象とする と、通信可能範囲が十分ではない（現在最大でも距 岸 $20 \mathrm{~km}$ 程度)。通信可能な範囲を広げるためにはレ ピータ中継機や基地局機能を中大型船に装備するこ とも有効である。今後、この点について詳細に検討 したい。

また携帯電話以外にも、国際VHF や漁業無線など、 既存の無線通信機の周波数を利用した新しい通信機 器についても可能性を検討したい。

\section{4. まとめ}

FRP 船のレーダ断面積を実測したレーダ受信電力 より求め、5 トン末満では約 $6 \mathrm{~m}^{2} 、 5$ トン以上では $15 \mathrm{~m}^{2}$ あるここがわかった。結果として、レーダレ フレクタのみによる電子的視認性の向上は効果が低 いことがわかり、その他の方法について調査・検討 した。
レーダおよび通信による新しい電子的視認性の向 上策として、带域外 Beacon や全船舶を対象とした共 通する通信方式について提案した。今後、実用化に 向けた検討を重稀ていく。

\section{謝辞}

最後に本研究において御協力をいただき、また平 畠をご指導いただいた井手麻奈美氏、観測で御協力 いただきました中條堌次郎氏、奥富雄司氏に哚く感 謝の意を表します。

\section{参考文献}

(1) 総務省 : 大型船と小型船の衝突海難について、情 報通信の HP より、平成 20 年 5 月

(2) Asoke K. Bhattacharyya, Dipak L. Sengupta : Radar Cross Section Analysis and Control, Artech House, 1991 (3) 落合徳臣、茂在寅男 : レーダの理論と実際、海文 堂、pp35-36、昭和 34 年 3 月

(4) 林尚吾: Radar Target Enhancer の危険性, 日本 航海学会誌 NAVIGATION, vol. 165, pp. 74-79, 平成 18 年 12 月

（5）（社）日本船舶品質管理協会：膨張式救命いかだ 及び救命胴衣艤装用の小型軽量 SART に関する調查 研究報告書、平成 15 年 3 月

（6）（社）電波産業会：簡易型船舶自動識別装置（簡 易型 AIS）導入のための周波数有効利用技術調查検 討報告書，平成 17 年 3 月

\section{質疑応答}

\section{鈴木治（鳥羽商船高専）:}

漁船用の通信システムとして、総務省側としては どのようなものを導入させたいのか、御存知でした ら教えて下さい。

\section{林尚吾}

平成 20 年 4 月から「海上における共通通信システム のあり方」として検討しており、本年（平成 20 年） 7 月には中間報告書がまとめられますので、機会を 見てお知らせしたいと考えます。 